\title{
Stages of health behavior change and factors associated with physical activity in patients with intermittent claudication
}

\author{
Estágios de mudança de comportamento e fatores associados à prática de atividade física \\ em indivíduos com claudicação intermitente
}

Jacilene Guedes de Oliveira1, João Paulo dos Anjos Souza Barbosa ${ }^{1,2}$, Breno Quintella Farah ${ }^{1}$, Marcel da Rocha Chehuen ${ }^{3}$, Gabriel Grizzo Cucato ${ }^{3}$, Nelson Wolosker ${ }^{4}$, Cláudia Lúcia de Moraes Forjaz ${ }^{3}$, Raphael Mendes Ritti Dias ${ }^{1,2}$

\begin{abstract}
Objective: To analyze, in people with intermittent claudication, the frequency of individuals who are in each of stages of health behavior change to practice physical activity, and analyze the association of these stages with the walking capacity. Methods: We recruited 150 patients with intermittent claudication treated at a tertiary center, being included those $\geq 30$-year-old-individuals and who had ankle-arm index $\leq 0.90$. We obtained socio-demographic information, presence of comorbidities and cardiovascular risk factors and stages of health behavior change to practice physical activity through a questionnaire, they being pre-contemplation, contemplation, preparation, action and maintenance. Moreover, the walking capacity was measured in a treadmill test (Gardner protocol). Results: Most individuals were in the maintenance stage $(42.7 \%)$, however, when the stages of health behavior change were categorized into active (action and maintenance) and inactive (pre-contemplation, contemplation and preparation), $51.3 \%$ of the individuals were classified as inactive behavior. There was no association between stages of health behavior change, sociodemographic factors and cardiovascular risk factors. However, patients with intermittent claudication who had lower total walking distance were three times more likely to have inactive behavior. Conclusion: Most patients with intermittent claudication showed an inactive behavior and, in this population, lower walking capacity was associated with this behavior.
\end{abstract}

Keywords: Peripheral artery disease; Exercise; Motor activity; Risk factors; Behavior

\section{RESUMO}

Objetivo: Analisar, em pessoas com claudicação intermitente, a frequência de indivíduos que está em cada um dos estágios de mudança de comportamento para a prática de atividade física bem como a relação desses estágios com a capacidade de caminhada. Métodos: Foram recrutados 150 indivíduos com claudicação intermitente atendidos em um centro terciário, sendo incluídos aqueles com idade $\geq 30$ anos e índice tornozelo braço $\leq 0,90$. Foram obtidos os dados sociodemográficos, sobre a presença de comorbidades e de fatores de risco cardiovascular e informações dos estágios de mudança de comportamento para a prática de atividade física, sendo eles pré-contemplação, contemplação, preparação, ação e manutenção. Além disso, a capacidade de caminhada foi obtida num teste de esforço em esteira (protocolo de Gardner). Resultados: A maior parte dos indivíduos encontrava-se no estágio de manutenção $(42,7 \%)$. Quando os estágios de mudança de comportamento foram categorizados em comportamento ativo (ação e manutenção) e inativo (pré-contemplação, contemplação e preparação), $51,3 \%$ dos indivíduos foram classificados com comportamento inativo. Não foi observada associação entre os estágios de mudança de comportamento e os fatores sociodemográficos e de risco cardiovascular. Contudo, os indivíduos com claudicação intermitente, que apresentaram uma menor distância total de caminhada, tinham três vezes mais chance de ter comportamento inativo. Conclusão: A maioria dos indivíduos com claudicação intermitente apresentou comportamento inativo e, nessa população, menor capacidade de caminhada foi associada a tal comportamento.

Descritores: Doença arterial periférica; Exercício; Atividade motora; Fatores de risco; Comportamento

\footnotetext{
Study carried out Hospital das Clínicas, Faculdade de Medicina, Universidade de São Paulo - USP, São Paulo (SP), Brazil.

${ }^{1}$ Research Group in Hemodynamics and Exercise Metabolism, Universidade de Pernambuco - UPE, Recife (PE), Brazil.

${ }^{2}$ Associated Graduate Program in Physical Education, Universidade de Pernambuco - UPE, Recife (PE), Brazil; Universidade Federal da Paraíba - UFPB, João Pessoa (PB), Brazil.

${ }^{3}$ Escola de Educação Física e Esporte, Universidade de São Paulo, USP - São Paulo (SP), Brazil.

${ }^{4}$ Hospital Israelita Albert Einstein - HIAE, São Paulo (SP), Brazil.

Corresponding author: Raphael Mendes Ritti Dias - Rua Arnóbio Marques, 310 - Santo Amaro - Zip code: 50100-130 - Recife (PE), Brazil - Phone: (55 81) 3183-3375 - E-mail: raphaelritti@gmail.com

Received on: Jul 4, 2012 - Accepted on: Oct 25, 2012
}

Conflict of interest: none. 


\section{INTRODUCTION}

Peripheral artery disease (PAD) affects approximately 27 million people in North America and Europe ${ }^{(1)}$. In Brazil, the prevalence of PAD is $10.5 \%$ in the population over 18 years and, of these, $9 \%$ have symptoms of intermittent claudication (IC) $)^{(2)}$. PAD is associated with increased risk of cardiovascular events, such as death, myocardial infarction, and stroke ${ }^{(3-5)}$. Physical activity practice is recommended in the treatment of individuals with IC, since it promotes improvements in walking ${ }^{(6,7)}$ and functional capacities ${ }^{(8)}$, and also in quality of life and mortality reduction in this population ${ }^{(9,10)}$. Despite these beneficial effects, adherence to physical activity programs is low among these patients ${ }^{(11)}$, which can be explained by the difficulty in changing physical inactivity habits acquired throughout life, especially in individuals with IC presenting pain during physical activity.

Some studies in the area of human behavior have observed that behavior change is influenced by environmental and personal factors ${ }^{(12)}$. According to the transtheoretical model, behavior changes occur in five stages, which represent the individual's level of readiness for behavior change ${ }^{(13)}$. In the first stage, called pre-contemplation, the individual has no interest in recognizing or modifying behavior. In the next stage, contemplation, the problem is recognized and there are intentions to change behavior, however, no effective action is taken. During the third stage, called preparation, there is an effort to adopt the new behavior, the individual is ready to start the behavior, for example, the adoption of physical activity practice in the near future, or has already adopted the behavior, but irregularly. In the action stage, the behavior change is evident enough to receive recognition from others. The last stage, maintenance, is characterized when the behavior change actually occurs and is maintained for more than 6 months.

Once the stage of health behavior change (SHBC) is determined, specific strategies for behavior change can be developed, according to which stage the individual is in, facilitating change ${ }^{(14)}$. Thus, determining SHBC in patients with IC may help increase adherence to physical activity practice. However, this has not yet been investigated in this population. Therefore, this study aimed to assess the frequency of SHBC for physical activity in individuals with IC. Moreover, since in these patients reduced walking capacity due to pain is an important factor in limiting physical activity, ${ }^{(15)}$ this study also aimed to examine the relation between walking ability and SHBC.

\section{OBJECTIVE}

To analyze - in IC patients - the frequency of individuals in each SHBC for physical activity and the relation of these stages with walking capacity.

\section{METHODS}

Characterization of the study, recruitment and screening This was a cross-sectional descriptive study. Patients were recruited in the Intermittent Claudication Outpatient Clinic of Hospital das Clínicas da Faculdade de Medicina da Universidade de São Paulo (FMUSP). During the period from February to July 2011, 440 patients were treated in this clinic. To be enrolled in the study, the individuals should be aged $\geq 30$ years, and have an ankle-brachial index $(\mathrm{ABI})<0.90$, limited walking capacity due to IC symptoms, and no mental disabilities identified using the Mini-Mental State Questionnaire ${ }^{(16)}$. According to these criteria, of the 440 attended patients, 158 were recruited, but eight individuals were excluded for not having returned for the second visit, and the final sample comprised 150 individuals.

Prior to data collection, subjects were informed about the procedures involved in the study and signed the informed consent form. This study was approved by the Research Ethics Committee of the Universidade de Pernambuco (UPE - 268/10) and of Hospital das Clínicas da FMUSP 0188/11).

\section{Diagnosis of PAD}

The diagnosis of PAD was determined using resting ABI. For this purpose, arm and ankle systolic blood pressures were measured simultaneously in triplicate. Measurements of ankle and arm blood pressure were performed with the use of vascular Doppler (Med Mega DV610, Brazil) equipment, and a mercury sphygmomanometer. Individuals who presented $\mathrm{ABI}<0.90$ at rest in one or two limbs were characterized as having PAD.

\section{Walking capacity}

To quantify walking capacity, a maximum treadmill exercise test (Inbrasport, model ATL, Brazil) was performed. A specific protocol for patients with IC was employed, with a constant speed of $3.2 \mathrm{~km} / \mathrm{h}$, and $2 \%$ increments on the slope every 2 minutes until exhaustion $^{(17)}$. All subjects were familiar with the test protocol before undergoing it for the study. The test was stopped when the subjects could no longer continue walking due to pain in the lower limbs. During the test, we recorded the time the patient reported the onset of 
pain symptoms, known as claudication distance (CD), and the maximum distance the patient was able to walk even with pain, known as total walking distance (TWD).

\section{General characteristics, comorbidities, and risk factors}

To obtain sociodemographic data, a questionnaire including data on age, race, socioeconomic status, educational level, and marital status was used. Furthermore, based on the medical records of patients at the hospital, some comorbidities (obesity, hypertension, diabetes, dyslipidemia, and heart disease) and cardiovascular risk factors (smoking habit and alcohol consumption) were identified.

\section{Stages of health behavior change}

For evaluation of SHBC for physical activity, a closed question with five alternatives was employed, as described previously ${ }^{(18)}$. In this question, the patients stated the situation that corresponded to their habits referring to the practice of regular physical activity during leisure time. The answer to the question allowed classifying each participant in one of the SHBC (precontemplation, contemplation, preparation, action, and maintenance).

\section{Statistical analysis}

For all analyses, we used the statistical program Statistical Package for the Social Sciences (SPSS) 18.0. Descriptive statistics procedures (frequency distribution) and measures of association (binary logistic regression and $\chi^{2}$ test) were used in the analyses. For the univariate analysis, the $\chi^{2}$ test was used to compare independent variables, such as sociodemographic and clinical characteristics, and cardiovascular risk factors, which were categorized as follows: age $(<60$ or $>60$ years), gender (male or female), ethnicity (White or non-White), educational level ( $<8$ years and $>8$ years), socioeconomic status (class $\mathrm{A}+\mathrm{B}$, and class $\mathrm{C}+\mathrm{D}+\mathrm{E}$ ), marital status (married/living with partner and single/ living without a partner); both $\mathrm{CD}(\mathrm{CD}<70 \mathrm{~m}$ or $\geq 70 \mathrm{~m})$ and TWD (TWD $<160 \mathrm{~m}$ or $\geq 160 \mathrm{~m}$ ) were obtained through the median. As to the study dependent variable, stages of health behavior change were categorized into active behavior (action and maintenance) and inactive behavior (pre-contemplation, contemplation, and preparation). A binary logistic regression was used to express the degree of association between variables. In the adjusted model, we included variables with $p<0.20$ and for possible confounding factors (gender, age, and $A B I$ ). In all analyzes $p<0.05$ was considered as significant.

\section{RESULTS}

The general characteristics of the subjects are described in table 1.

The mean age of subjects was $>60$ years. More than half of the sample were men, overweight, married, White, and who had studied for more than 8 years. Regarding family income, half of the sample was in class B. The comorbidity with the highest prevalence was hypertension, followed by dyslipidemia, heart disease and diabetes. Current smoking habit was reported by $24 \%$ of patients.

\begin{tabular}{|c|c|}
\hline Variables & n (\%) \\
\hline \multicolumn{2}{|l|}{ Gender } \\
\hline Male & $95(63)$ \\
\hline Female & $55(37)$ \\
\hline \multicolumn{2}{|l|}{ Ethnicity } \\
\hline White & $93(62)$ \\
\hline Non-white & $57(38)$ \\
\hline \multicolumn{2}{|l|}{ Educational level } \\
\hline Up to junior school & $108(72)$ \\
\hline High school or further education & $42(28)$ \\
\hline \multicolumn{2}{|l|}{ Economic class } \\
\hline Class $A$ - up to $R \$ 9,850.00$ & $19(13)$ \\
\hline Class $B$ - up to $R \$ 2,950.00$ & $76(50)$ \\
\hline Class $C$ - up to $R \$ 1,100.00$ & $39(26)$ \\
\hline Class $D$ - up to $R \$ 750.00$ & $15(10)$ \\
\hline Class $E$ - up to $R \$ 410.00$ & $1(1)$ \\
\hline \multicolumn{2}{|l|}{ Marital status } \\
\hline Married/living with partner & $102(68)$ \\
\hline Single/living without a partner & $48(32)$ \\
\hline \multicolumn{2}{|l|}{ Comorbidities } \\
\hline Hypertension & $118(79)$ \\
\hline Dyslipidemia & $107(71)$ \\
\hline Heart diseases & $86(57)$ \\
\hline Diabetes & $59(39)$ \\
\hline Smoking & $36(24)$ \\
\hline Clinical factors & Mean $( \pm S D)$ \\
\hline Body mass index $\left(\mathrm{kg} / \mathrm{m}^{2}\right)$ & $26.3(4.5)$ \\
\hline Ankle-brachial index & $0.58(0.14)$ \\
\hline Waist circumference $(\mathrm{cm})$ & $94.2(11.4)$ \\
\hline Waist-hip ratio & $0.94(0.07)$ \\
\hline Claudication distance $(\mathrm{m})$ & $173.9(146.9)$ \\
\hline Total walking distance $(\mathrm{m})$ & $396.4(284.6)$ \\
\hline
\end{tabular}


Figure 1 presents the distribution of individuals with IC in each SHBC for physical activity. The majority of the sample $(42.7 \%)$ was in the maintenance stage, followed by the preparation stage. A smaller proportion $(6 \%)$ was found in the action stage. Of all individuals, $51.3 \%$ were classified in the inactive behavior (precontemplation, contemplation, and preparation) and $48.7 \%$ in the active behavior (action and maintenance).

Table 2 shows the sociodemographic characteristics according to SHBC in individuals with IC. No relation

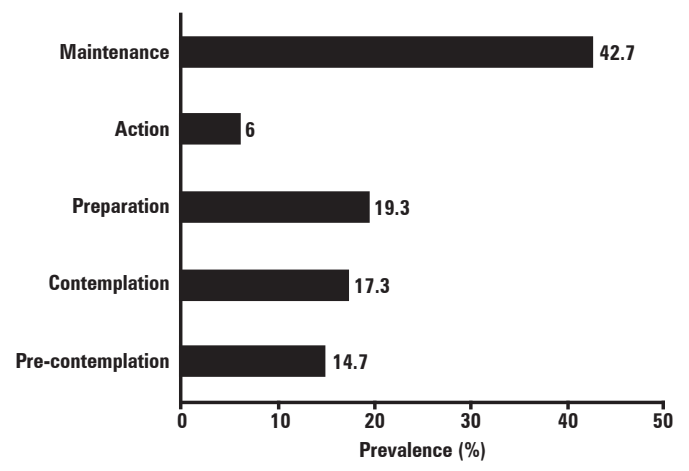

Figure 1. Distribution of individuals with intermittent claudication per stages of health behavior change

Table 2. Prevalence of stages of health behavior change according to sociodemographic characteristics in individuals with intermittent claudication

\begin{tabular}{|c|c|c|c|}
\hline \multirow[t]{2}{*}{ Variables } & \multirow{2}{*}{$\begin{array}{c}\begin{array}{c}\text { Active } \\
\text { behavior }\end{array} \\
\mathbf{n}(\%)\end{array}$} & \multirow{2}{*}{$\begin{array}{c}\begin{array}{c}\text { Inactive } \\
\text { behavior }\end{array} \\
\mathbf{n}(\%)\end{array}$} & \multirow[t]{2}{*}{ p-value* } \\
\hline & & & \\
\hline Gender & & & 0.549 \\
\hline Male & $48(50.5)$ & $47(49.5)$ & \\
\hline Female & $25(45.5)$ & $30(54.5)$ & \\
\hline Age (years) & & & 0.634 \\
\hline$\leq 60$ & $22(45.8)$ & $26(54.2)$ & \\
\hline$>60$ & $51(50.0)$ & $51(50.0)$ & \\
\hline Marrital status & & & 0.900 \\
\hline Married/living with partner & $50(49.0)$ & $52(51.0)$ & \\
\hline Single/living without a partner & $23(47.9)$ & $25(52.1)$ & \\
\hline Ethnicity & & & 0.273 \\
\hline White & $42(45.2)$ & $51(54.8)$ & \\
\hline Non-white & $31(54.4)$ & $26(45.6)$ & \\
\hline Educational level & & & 0.195 \\
\hline Up to junior school & $49(45.4)$ & $59(54.6)$ & \\
\hline High school or further & $24(57.1)$ & $18(42.9)$ & \\
\hline Average family income & & & 0.348 \\
\hline Class A+B & $49(67.1)$ & $46(59.7)$ & \\
\hline Class $C+D+E$ & $24(32.9)$ & $31(40.3)$ & \\
\hline
\end{tabular}

${ }^{*} \chi^{2}$ test. was found between SHBC and sociodemographic characteristics $(\mathrm{p}>0.05)$.

Table 3 presents the clinical characteristics and cardiovascular risk factors, according to SHBC in patients with IC. The prevalence of lower TWD was higher in individuals classified as inactive than in those classified as active $(\mathrm{p}=0.004)$.

In the adjusted analysis (Table 4), it was observed that individuals with low TWD were three times more likely to present inactive behavior $(\mathrm{p}=0.048)$.

Table 3. Prevalence of stages of health behavior change according to clinical characteristics, comorbidities and cardiovascular risk factors in individuals with intermittent claudication

\begin{tabular}{|c|c|c|c|}
\hline Variables & $\frac{\text { Active behavior }}{\mathrm{n}(\%)}$ & $\frac{\text { Inactive behavior }}{\mathrm{n}(\%)}$ & p-value* \\
\hline Ankle-brachial index & & & 0.652 \\
\hline$<0.60$ & $40(52.9)$ & $45(47.1)$ & \\
\hline $0.61-0.90$ & $33(50.8)$ & $32(49.2)$ & \\
\hline Claudication distance (m) & & & 0.067 \\
\hline$<70$ & $15(38.5)$ & $24(61.5)$ & \\
\hline$\geq 70$ & $52(55.9)$ & $41(44.1)$ & \\
\hline Total walking distance $(\mathrm{m})$ & & & 0.004 \\
\hline$<160$ & $10(29.4)$ & $24(70.6)$ & \\
\hline$\geq 160$ & $58(58.0)$ & $42(42.0)$ & \\
\hline Obesity & & & 0.214 \\
\hline Yes & $48(65.8)$ & $43(55.8)$ & \\
\hline No & $25(34.2)$ & $34(44.2)$ & \\
\hline Diabetes & & & 0.364 \\
\hline Yes & $26(44.1)$ & $33(55.9)$ & \\
\hline No & $47(51.6)$ & $44(48.4)$ & \\
\hline Arterial hypertension & & & 0.305 \\
\hline Yes & $60(50.8)$ & $58(49.2)$ & \\
\hline No & $13(40.6)$ & $19(59.4)$ & \\
\hline Dyslipidemia & & & 0.267 \\
\hline Yes & $49(45.8)$ & $58(54.2)$ & \\
\hline No & $24(55.8)$ & $19(44.2)$ & \\
\hline Heart diseases & & & 0.540 \\
\hline Yes & $40(46.5)$ & $46(53.5)$ & \\
\hline No & $33(51.6)$ & $31(48.4)$ & \\
\hline Smoking & & & 0.561 \\
\hline Yes & $16(21.9)$ & $20(26.0)$ & \\
\hline No & $57(78.1)$ & $57(74.0)$ & \\
\hline Alcohol & & & 0.588 \\
\hline Yes & $10(43.5)$ & $13(56.5)$ & \\
\hline No & $63(49.6)$ & $64(50.4)$ & \\
\hline
\end{tabular}


Table 4. Analysis of crude and adjusted logistic regression and respective $95 \%$ confidence intervals $(95 \% \mathrm{Cl})$ for educational level, claudication distance and total walking distance, considering the stages of health behavior change as dependent variable

\begin{tabular}{lcc}
\hline Variables & $\begin{array}{c}\text { Crude } \mathbf{~ O R} \\
\mathbf{( 9 5 \%} \mathbf{~ C l )}\end{array}$ & $\begin{array}{c}\text { Adjusted OR } \\
\mathbf{( 9 5 \%} \mathbf{~ C l )} \mathbf{*}^{*}\end{array}$ \\
\hline $\begin{array}{l}\text { Educational level } \\
\text { Up to junior school }\end{array}$ & $1.61(0.78-3.29)$ & $1.67(0.73-3.84)$ \\
High school or further education & 1 & 1 \\
Claudication distance $(\mathrm{m})$ & & \\
$<70$ & $2.03(0.95-4.36)$ & $0.82(0.27-2.48)$ \\
$\geq 70$ & 1 & 1 \\
Total walking distance $(\mathrm{m})$ & & 1 \\
$<160$ & $3.31(1.43-7.66)$ & $2.92(1.03-8.48)^{* *}$ \\
$\geq 160$ & 1 & 1 \\
\hline
\end{tabular}

${ }^{*}$ Adjusted for other independent variables and for gender, age and ankle-brachial index; ${ }^{* *} p<0.05$.

\section{DISCUSSION}

The main results of this study were the following: maintenance stage stood out among individuals with IC, presenting a percentage of 42.7 ; the prevalence of individuals with inactive behavior was $51.3 \%$; inactive behavior was associated with the lowest walking capacity.

The findings of this study also showed that $42.7 \%$ of patients with IC were in the maintenance stage for physical activity. These data are similar to those observed in elderly subjects without PAD, in which, according to a study conducted by Willrich ${ }^{(19)}$ with 107 elderly, in the city of Três Coroas in southerm region of Brazil, $45.8 \%$ of the elderly were in the maintenance stage. A similar prevalence of patients with IC in the maintenance stage compared to individuals without the disease can be explained by the fact that, in the present study, the recruitment of patients was conducted in an outpatient clinic, in which physical exercise is part of the main therapeutic recommendation, and is encouraged by a multidisciplinary team composed of physicians and physical education professionals.

Although a large percentage of the sample was in the maintenance stage, when the analysis was performed by grouping the patients according to active or inactive behavior, it was observed that more than half $(51.3 \%)$ presented inactive behavior. These results corroborate the study conducted by Brazão et al., ${ }^{(20)}$ who observed that $50.5 \%$ of the elderly patients in the sample did not practice and had no interest in physical activity over the next 6 months (pre-contemplation) and a small portion did not practice physical activity, but planned to practice in the near future (contemplation and preparation). In another study, conducted with institutionalized elderly patients, it was found that $76 \%$ of individuals presented inactive behavior, and, of these, $56 \%$ were in the pre-contemplation stage, followed by contemplation and preparation stages ${ }^{(21)}$.

The process of health behavior change requires strategies and activities that aim at advancing the patient to the next stage. Thus, an intervention is recommended for different individuals in different $\mathrm{SHBC}^{(22)}$. For individuals in the pre-contemplation stage, it is important to educate, sensitize and encourage an appreciation of physical activity. For those in the contemplation stage, the performance of physical activities may be encouraged, because most of them have the intention to change behavior. For individuals in the preparation stage, it is important to offer appropriate programs for them to practice, because they express interest in physical activity in the near future ${ }^{(23,24)}$. Therefore, these distinct strategies to promote physical activity should be used according to the patients' SHBC.

In this study, individuals with inactive behavior were associated with lower walking capacity. A possible explanation for this is that patients with greater functional limitation practice less physical activity, aiming to avoid the onset of claudication symptoms ${ }^{(15)}$. Moreover, it seems that the stage of disease is related to the functional limitation in these individuals, since the higher the degree of complication of the disease, the lower the interest for physical activity ${ }^{(25,26)}$. Another aspect that may have contributed to inactive behavior is the reduced levels of muscular strength and endurance in patients with $\mathrm{IC}^{(27)}$, since such losses in muscle function affect physical function ${ }^{(28)}$. According to the findings in the literature, decreased strength in claudication directly related to walking capacity ${ }^{(29,30)}$. Therefore, it is important that individuals with greater limitation receive additional encouragement for physical activity.

This study had some limitations that should be considered. The lack of monitoring of physical activities which the patients engaged in during the period of data collection rendered it impossible to conclude whether the change in behavior was actually attributed to the practice of physical activity. Additionally, the study used a cross-sectional design, which does not determine cause and effect.

\section{CONCLUSION}

Individuals with IC presented inactive behavior, and, in this population, lower walking capacity was associated with this behavior. 


\section{ACKNOWLEDGEMENTS}

The authors thank the Coordination for the Improvement of Higher Education Personnel (CAPES) for the Master's degree scholarship granted.

\section{REFERENCES}

1. B Belch JJ, Topol EJ, Agnelli G, Bertrand M, Califf RM, Clement DL, Creager MA, Easton JD, Gavin JR 3rd, Greenland P, Hankey G, Hanrath P, Hirsch AT, Meyer J, Smith SC, Sullivan F, Weber MA; Prevention of Atherothrombotic Disease Network. Critical issues in peripheral arterial disease detection and management: a call to action. Arch Intern Med. 2003;163(8):884-92.

2. Makdisse MR, Pereira AC. Prevalência e fatores de risco associados à doença arterial periférica no Projeto Corações do Brasil. Arq Bras Cardiol. 2008; 91(6):370-82.

3. Criqui MH, Langer RD, Fronek AM, Feigelson HS, Klauber MR, McCann TJ, et al. Mortality over a period of 10 years in patients with peripheral arterial disease. N Engl J Med. 1992;326(6):381-6.

4. Howell MA, Colgan MP, Seeger RW, Ramsey DE, Sumner DS. Relationship of severity of lower limb peripheral vascular disease to mortality and morbidity: a six-year follow-up study. J Vasc Surg. 1989;9(5):691-7.

5. McDermott MM, Feinglass J, Slavensky R, Pearce WH. The ankle-brachial index as a predictor of survival in patients with peripheral vascular disease. $\mathrm{J}$ Gen Intern Med. 1994;9(8):445-9.

6. Askew CD, Green S, Walker PJ, Kerr GK, Green AA, Williams AD, et al. Skeletal muscle phenotype is associated with exercise tolerance in patients with peripheral arterial disease. J Vasc Surg. 2005;41(5):802-7.

7. Ritti-Dias RM, Wolosker N, Forjaz CL, Carvalho CR, Cucato GG, Leão PP, et al. Strength training increases walking tolerance in intermittent claudication patients: randomized trial. J Vasc Surg. 2010;51(1):89-95.

8. Sudbrack AC, Leite RS. Efetividade do exercício na claudicação. Rev Bras Cardiol Invas. 2007;15(3):261-6.

9. Hirsch AT, Haskal ZJ, Hertzer NR, Bakal CW, Creager MA, Halperin JL, Hiratzka LF, Murphy WR, Olin JW, Puschett JB, Rosenfield KA, Sacks D, Stanley JC, Taylor LM Jr, White CJ, White J, White RA, Antman EM, Smith SC Jr, Adams CD, Anderson JL, Faxon DP, Fuster V, Gibbons RJ, Hunt SA, Jacobs AK, Nishimura R, Ornato JP, Page RL, Riegel B; American Association for Vascular Surgery; Society for Vascular Surgery; Society for Cardiovascular Angiography and Interventions; Society for Vascular Medicine and Biology; Society of Interventional Radiology; ACC/AHA Task Force on Practice Guidelines Writing Committee to Develop Guidelines for the Management of Patients With Peripheral Arterial Disease; American Association of Cardiovascular and Pulmonary Rehabilitation; National Heart, Lung, and Blood Institute; Society for Vascular Nursing; TransAtlantic Inter-Society Consensus; Vascular Disease Foundation. ACC/AHA 2005 Practice Guidelines for the Management of Patients With Peripheral Arterial Disease (Lower Extremity, Renal, Mesenteric, and Abdominal Aortic): A Collaborative Report from the American Association for Vascular Surgery/Society for Vascular Surgery, ${ }^{*}$ Society for Cardiovascular Angiography and Interventions, Society for Vascular Medicine and Biology, Society of Interventional Radiology, and the ACC/AHA Task Force on Practice Guidelines (Writing Committee to Develop Guidelines for the Management of Patients With Peripheral Arterial Disease): Endorsed by the American Association of Cardiovascular and Pulmonary Rehabilitation; National Heart, Lung, and Blood Institute; Society for Vascular Nursing; TransAtlantic Inter-Society Consensus; and Vascular Disease Foundation. Circulation. 2006;113(11):e463-654.

10. Menêses AL, Lima AH, Farah BQ, Silva GQ, Lima GH, Lins Filho OL, et al. Correlation between physical fitness and indicators of quality of life of individuals with intermittent claudication. Rev Bras Med Esp. 2011;17(3):175-8.
11. Wolosker N, Nakano L, Rosoky RA, Puech-Leao P. Evaluation of walking capacity over time in 500 patients with intermittent claudication who underwent clinical treatment. Arch Intern Med. 2003;163(19):2296-300.

12. Sherwood NE, Jeffery RW. The behavioral determinants of exercise: implications for physical activity interventions. Annu Rev Nutr. 2000;20(1):21-44.

13. Prochaska J0, Marcus BH. The transtheoretical model: applications to exercise. England: Human Kinetics Publishers; 1994.

14. Spencer L, Adams TB, Malone S, Roy L, Yost E. Applying the transtheoretical model to exercise: a systematic and comprehensive review of the literature. Health Promot Pract. 2006;7(4):428-43

15. Gardner AW, Montgomery PS, Afaq A. Exercise performance in patients with peripheral arterial disease who have different types of exertional leg pain. J Vasc Surg. 2007;46(1):79-86.

16. Almeida OP. Mini exame dos estado mental eo diagnóstico de demência no Brasil. Arq Neuropsiquiatr. 1998;56(3B):605-12.

17. Gardner AW, Skinner JS, Cantwell BW, Smith L. Progressive vs single-stage treadmill tests for evaluation of claudication. Med Sci Sports Exerc. 1991; 23(4):402-8.

18. Barros MV. Atividades físicas no lazer e outros comportamentos relacionados à saúde dos trabalhadores da indústria no Estado de Santa Catarina [tese]. Florianópolis: Centro de Desportos, Universidade Federal de Santa Catarina; 1999.

19. Willrich C. Determinantes da prática de atividades físicas e estágios de mudança de comportamento em uma amostra de idosos pertencentes a grupos de $3^{0}$ idade de Três Coroas [tese]. Rio Grande do Sul: Centro Universitário Feevale; 2008.

20. Brazão MC, Hirayama MS, Gobbi S, Crispim Nascimento CM, Roseguini AZ. Estágios de mudança de comportamento e barreiras percebidas à prática de atividade física em idosos residentes em uma cidade de médio porte do Brasil. Motriz. 2009;15(4):759-67.

21. Gobbi S, Carita LP, Hirayama MS, Quadros AC, Santos RF, Gobbi LT Comportamento e Barreiras: Atividade Física em Idosos Institucionalizados. Psicol. 2008;24(4):451-8.

22. Prochaska JO, DiClemente CC, Norcross JC. In search of how people change. Applications to addictive behaviors. Am Psychol. 1992;47(9):1102-14.

23. Norris SL, Grothaus LC, Buchner DM, Pratt M. Effectiveness of physicianbased assessment and counseling for exercise in a staff model HMO. Prev Med. 2000;30(6):513-23.

24. Quadros TM, Petroski EL, Santos-Silva DA, Pinheiro-Gordia A. The prevalence of physical inactivity amongst Brazilian university students: its association with sociodemographic variables. Rev Salud Publica (Bogota). 2009;11(5):724-33.

25. Gardner AW, Clancy RJ. The relationship between ankle-brachial index and leisure-time physical activity in patients with intermittent claudication. Angiology. 2006;57(5):539-45.

26. Gardner AW, Womack CJ, Sieminski DJ, Montgomery PS, Killewich LA Fonong T. Relationship between free-living daily physical activity and ambulatory measures in older claudicants. Angiology. 1998;49(5):327-37.

27. Menêses AL, Farah BO, Ritti-Dias RM. Função muscular em indivíduos com doença arterial obstrutiva periférica: uma revisão sistemática. Motricidade. 2012;8(1):86-96.

28. McDermott MM, Criqui MH, Greenland P, Guralnik JM, Liu K, Pearce WH, et al. Leg strength in peripheral arterial disease: associations with disease severity and lower-extremity performance. J Vasc Surg. 2004;39(3):523-30.

29. Gerdle B, Hedberg B, Angquist K, Fugl-Meyer A. Isokinetic strength and endurance in peripheral arterial insufficiency with intermittent claudication. Scand J Rehabil Med. 1986:18(1):9-15.

30. Regensteiner JG, Wolfel EE, Brass EP, Carry MR, Ringel SP, Hargarten ME, et al. Chronic changes in skeletal muscle histology and function in peripheral arterial disease. Circulation. 1993;87(2):413-21. 